\title{
Frontier Foundations for Revolution
}

Shaanxi has been both central and peripheral to the course of Chinese history. In ancient times it was the core of Chinese civilization. The alleged tomb of the legendary Yellow Emperor lies 150 kilometers north of the provincial capital. The first emperor established his capital near Xi'an, and from the third century BCE to the tenth century $\mathrm{CE}$ the great ancient dynasties were centered here. In modern times, as we shall see, Generalissimo Chiang Kai-shek was kidnapped by his own generals in Xian, held hostage until he agreed to join the Communists in a united front against Japanese aggression. And yet, despite this ancient eminence and recent notoriety, Shaanxi in modern times has been a backwater, far from the economic and political centers in Shanghai and Beijing, relegated to a position in what was called the Northwest, a "backward" region in need of opening and development (kaifa xibei 开发西北). In the words of an early twentieth-century American visitor, "It is old and isolated ... so isolated that the Pekinese speak of it as though it were a foreign country."

The ancient capitals were established in Guanzhong, the area "between the passes" in the fertile valley of the Wei River. The Wei River valley extends three hundred kilometers from west to east, with low hills separating it from Gansu to the west, and the formidable Tongguan (潼關) Pass, which Westerners called "the Gibraltar on the Yellow River," protecting Guanzhong from enemies on the North China plain to the east. ${ }^{2}$ Guanzhong is bordered on the south by the Qinling (秦岭) range, which separates the rich rice-growing regions of South China from the arid wheat and millet fields of the north. The moisture-bearing monsoon rains of summer originate in the southern oceans, and their progress north is blocked by each successive mountain range. The Wei River valley is well watered in the rain shadow of the Qinling, and the plain north of the Wei is broad and well served by irrigation canals that date from ancient times (see map 1). ${ }^{3}$ 


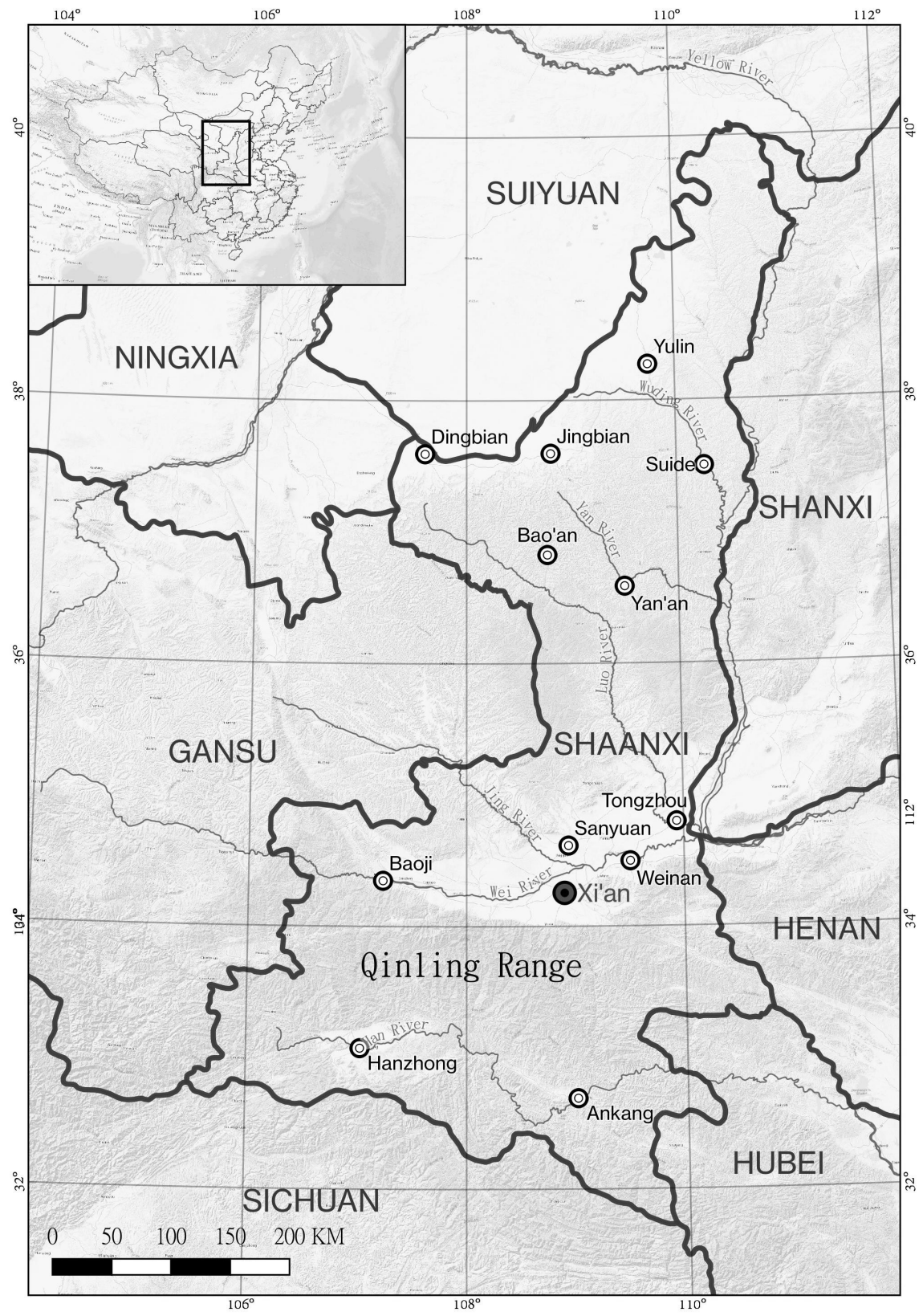

MAP 1. Shaanxi geography. 
South of the Qinling range lies southern Shaanxi (Shaannan 陕南) on the upper reaches of the Han River, which flows into the Yangzi at Wuhan. Before the nineteenth century, this was still a frontier region, far from the centers of political power, that attracted unruly migrants. In the late eighteenth century, it was wracked by a persistent White Lotus Rebellion that took years for the Qing authorities to suppress. ${ }^{4}$ In the modern era, the regular rains south of the Qinling and the gradual expansion of trade up the Han River gave a decent level of prosperity to the region. ${ }^{5}$ In 1936-37, after the Long March brought the Red Army to northern Shaanxi, Mao Zedong wished to transfer his forces to this richer Shaannan region, but Chiang Kai-shek preferred to keep the Communists bottled up in the poorer hills of the north.

Northern Shaanxi, with Yan'an at its center, is our main concern. This is where the local Communists established their base in the 1930s, where the Long March ended in 1935, and where the Communist Party established its headquarters during the long War of Resistance against Japan (1937-45). The north is unquestionably the poorest part of Shaanxi Province, indeed one of the poorest regions of the empire. Annual rainfall in Shaanxi decreases as one moves north, with the Qinling mountains blocking the southern storms, and the Lüliang mountains (吕梁山) in Shanxi to the east checking humid air from the Pacific. Republican era (1912-49) figures put annual rainfall at one-third the Xi'an average, while presumably more systematic contemporary statistics suggest that around Yan'an it was one half that of Shaannan, and perhaps two-thirds of the Guanzhong heartland. Within Shaanbei, rainfall decreases as one moves north toward the Great Wall and the Gobi Desert beyond. Throughout the region, rainfall is less reliable than in Guanzhong, more concentrated in a few summer months, and often coming in torrential downpours that erode the hillsides. The northern latitude leaves the frost-free agricultural growing seasons significantly shorter, and yields lower, than on the southern plains. ${ }^{6}$

Chinese accounts, ancient and modern, invariably describe Shaanbei as a land where “the soil is barren and the people are poor" (diji minpin 地㾉民贫). ${ }^{7}$ In fact, except in the far north, where spring winds from the Gobi Desert bring sandstorms that add grit to the soil, most of Shaanbei is covered by a thick layer of the same loess soil that covers most of the Northwest. ${ }^{8}$ The whole area, including much of eastern Gansu, forms China's loess plateau, the thick loess layer a product of millennia of blown dust deposits that combined with decomposed grasses adding rich organic material to the soil. Loess soil readily absorbs and retains rainwater, which is then drawn to the surface to nourish crops. ${ }^{9}$ Shaanbei's soil is not barren, but Shaanbei differs from other regions of the province in that rainfall is too scarce and unreliable to add moisture to the soil. In addition, the rivers cut deep gorges, leaving little level valley land for irrigated cultivation. Most Shaanbei fields are on high plateaus or rounded treeless hillsides and depend entirely on adequate rainfall at appropriate points of the growing season. To make matters worse, 
the Luo River (洛河), which cuts through Shaanbei from northwest to southeast, originates in the acrid lands of northeastern Gansu and carries flood waters heavy in salt that are unsuitable for irrigation and damage the limited fields on the valley floor. ${ }^{10}$

Sparse rainfall kept population density low, and the barren hills provided little organic material to nourish the soil. This led to a form of extensive agriculture that frustrated Communist cadres eager for increased production. Especially after the nineteenth-century rebellions drastically reduced the population along the Gansu border, there was plentiful land available, and peasants developed the habit of moving to new fields as the soil was depleted, rather than applying fertilizer to enhance productivity on the land under cultivation. As one report put it: "The local peasants use little fertilizer, often applying none at all to hill land and little on the valley floor." ${ }^{\prime 1}$ The harsh environment and the peasants' response to it left the area desperately poor. When a consular officer visited Yan'an in the early Republic, he called it "the centre of the most desolate area, by far the poorest region I have traversed in China outside the actual deserts." ${ }^{12}$ Edgar Snow concurred, calling it "one of the poorest parts of China I had seen."13 Snow's wife, visiting a year after his historic 1936 trip to the Communist base, agreed that she had "never seen such poverty as among the peasants in Shensi, where famine is perennial." ${ }^{14}$

\section{ANCIENT FRONTIER}

Modern Shaanbei may have been unbearably poor, but it had a proud if troubled ancient history. Most local accounts begin with the battles of the thirdcentury BCE Qin general Meng Tian against the nomadic Xiongnu invaders to the north, and his supposed grave near the town of Suide is still the object of veneration..$^{15}$ With the ancient capital in Xi'an, northern Shaanxi was a strategic corridor for incursions from the Central Asian steppe, a contested zone on the frontier between sedentary agriculturalists and horseback nomads. Modern histories are often constructed around a narrative of ancient glory in defense of the empire and a lamented era of modern decline. ${ }^{16}$ In the Song dynasty (960-1279), northern Shaanxi was divided and contested with the Tangut Western Xia kingdom, with the noted Chinese scholar Fan Zhongyan directing the defense from Yanan, leaving writings, poems, and steles for later ages to revere. A border garrison was located at the town of Jintang, the twentieth-century home of Liu Zhidan, hero of the Shaanbei revolution. ${ }^{17}$

The Ming dynasty (1368-1644) followed almost a century of Mongol rule. In its early years, the Ming pursued an aggressive policy to subdue its Mongol foes, but after this strategy led to disastrous defeats including the capture of one Ming emperor, the court shifted to a more defensive posture. The new policy generated China's great age of wall building, with Shaanbei a critical and costly line of defense. Over the fifteenth and sixteenth centuries a stamped earth wall with intermittent signal towers manned by small garrisons was built across the northernmost 
counties of Shaanbei. The wall was just south of the Ordos Desert, which separated Shaanbei from the great northern bend of the Yellow River. ${ }^{18}$ The headquarters for this section of the wall was the town of Yulin (榆林), on the edge of the desert in northeastern Shaanxi. The commander there oversaw a section of the wall that stretched from Shanxi across all of Shaanbei and into what are now Gansu and Ningxia to the west. The Ming statutes called for 55,379 soldiers with 33,105 horses, camels, and mules. ${ }^{19}$ This large military establishment was supposed to be selfsupporting, growing its own provisions in military colonies (tuntian 屯田) that occupied most of the land along the northern border. But the land here was poor to begin with and the colonies enhanced deforestation, which further degraded the local ecology. The soldiers, most of whom were recruited elsewhere, were not efficient farmers in the far north. As a result, most of the fields were rented to local peasants. The soldiers were regarded as “guests” (kebing 客兵) whose expenses were more than Shaanbei could provide, requiring substantial infusions from the imperial treasury. ${ }^{20}$

This whole system came crashing down in the seventeenth century, with disastrous consequences for both Shaanbei and the Ming dynasty. Having ruled China for over two centuries, the Ming was showing predictable signs of corruption, discord, and decay. In the 1590s, a protracted war in Korea, sparked by the invasion of Japan's new strongman Hideyoshi, had seriously strained the dynasty's finances. Then came the rising challenge of the Manchus in the Northeast, who would soon conquer the Ming and establish their own dynasty, the Qing, in 1644. Making matters worse, the entire globe was enduring falling temperatures and failing harvests in the Maunder Minimum, sometimes referred to as the Little Ice Age. ${ }^{21}$ Colder weather, a reduced growing season, and then a period of prolonged drought brought the Shaanbei agricultural economy to the point of collapse. It was precisely in Shaanbei that the rebellions began that toppled the Ming.

Drought and famine began in 1628 with the usual consequences: people fed on bark and leaves, wives were sold, children were abandoned, and there were frequent reports of cannibalism. With imperial finances strapped, soldiers went unpaid and official posthouses were closed, throwing their employees out of work. With refugees foraging for food, ex-soldiers and petty functionaries formed the leadership of bandit gangs that turned to looting and violence to survive. Large bands in fancy clothes stolen from the rich could number in the thousands, though they were armed mostly with spears, swords, and farm tools. The two most famous rebel chieftains came from Shaanbei. Zhang Xianzhong had been a soldier near Yan'an, rebelled in 1630, and ended his career as a psychopathic killer who decimated the western province of Sichuan. His more moderate and successful rival was Li Zicheng from Mizhi, a groom from a post station that was closed in the Ming budget cuts. It was Li Zicheng who ultimately captured Beijing to topple the Ming dynasty in 1644, before the Manchus entered the struggle and drove him back to Shaanbei and his demise. ${ }^{22}$ 
Li Zicheng and Zhang Xianzhong were certainly the most famous peasant rebels to emerge from Shaanbei, and Li did harbor a certain affection for his homeland, returning to rename his native county "Protected by Heaven” (Tianbao 天保), building a palace and restoring his family's ancestral tombs that the local elite had dug up and destroyed. ${ }^{23}$ To this day there is a large and gaudy temple in his honor in Mizhi. However, both $\mathrm{Li}$ and Zhang soon abandoned Shaanbei to campaign and forage in richer areas of southern Shaanxi, the North China plain, and, in Zhang Xianzhong's case, the Yangzi valley. ${ }^{24}$ Shaanbei, however, did not return to peace. Instead, the ground was occupied by lesser rebels who went by such colorful names as “Never Muddy” (Buzhanni 不沾泥), “Monk Wang” (王和尚), and “Top God” (Shenyikui神一鬼). ${ }^{25}$ Poorly armed and lacking many firearms, the rebels were rarely able to take walled towns or cities but instead ravaged the countryside for years on end. ${ }^{26}$ On the government side, military weakness led to counterproductive tactical decisions. On the one hand, the cost of confining and feeding prisoners produced a preference for summary executions. When commanders were offered bonuses for head counts, the result was the needless slaughter of innocents. When this engendered the predictable resistance, the policy shifted to encouraging rebels to surrender with offers of clemency and positions in the depleted armed forces. But that only resulted in repeated rebel surrenders (including key leaders like Li Zicheng) when they found themselves trapped, only to have them rise again after a period of rest and recuperation. The whole bloody process finally ended when the Manchus entered China, proclaimed the new Qing dynasty in Beijing, and sent a large force of Manchu and Mongol cavalry to cross the Yellow River into Shaanbei and suppress the remaining rebel bands. ${ }^{27}$

QING RULE: PEACE, RECOVERY,

AND ONGOING POVERTY

The Manchus were frontier conquerors from the Northeast allied with Mongol cavalrymen from the northern steppe. Tracing their legitimacy to the great steppe empires of Genghis Khan, the Manchus held a conception of empire that extended well beyond the ethnically Han empires of the past. During the course of the long Qing dynasty (1644-1911), Manchu banners, as their military units were called, campaigned in the north and west to incorporate all of Mongolia, Tibet, and the Turkic regions now known as Xinjiang. ${ }^{28}$ With this expanded conception of empire, the Northwest assumed new strategic significance during the Qing. Xian housed the first and largest Manchu garrison outside of Beijing, and there were other large military bases along the Yellow River in Ningxia to the northwest and guarding the entrance to Shaanxi at Tongguan in the east. Together, these garrisons would consume up to a quarter of the provincial budget. ${ }^{29}$ Throughout the Qing, Shaanxi would be logistically critical in support of military campaigns both on Sichuan's Tibetan borderlands and in Xinjiang. This was the case both for the eighteenth-century conquest of the west and for its reconquest after the rebellions 
of the nineteenth century. ${ }^{30}$ Given this critical strategic position, it is not surprising that through most of the Qing only Manchus served as governor or governorgeneral in Shaanxi. ${ }^{31}$

While this new strategic role placed increased burdens on the province, there was one important respect in which Qing rule reduced the demands on Shaanbei. The Ming had invested heavily in constructing the Great Wall across northern Shaanxi, and the expense of construction and the large garrisons necessary for defense imposed significant burdens on the local peasants. We have seen in the rebellions of the late Ming the depth of the discontent that this caused, especially when sparked by natural disasters for which the government was unable to provide relief. Now under the Qing, the Mongols were included within the empire, their princes incorporated into the ruling coalition. The border between agrarian and nomadic cultures had disappeared and with it the need to defend the Great Wall. The military headquarters in Yulin remained-and its prosperous walled city would continue as the Shaanbei center of military power through the republican erabut seven of the ten Ming offices were closed, and the official quota for soldiers on the frontier was reduced from fifty-five thousand to nine thousand. ${ }^{32}$

With peace restored to the frontier, markets opened for trade with the Mongols. The most prominent items of trade were wool, fur, and hides, all coming from the sheep, goats, and other herds in the region. Mongols were eager participants in this trade, exchanging the products of their herds for tea, cloth, liquor, tobacco, and other goods from the Chinese heartland. Firearms were strictly banned from this trade, there being limits to official trust of mobile Mongol bands on the vast northern grasslands. ${ }^{33}$ A significant trade route opened on the flatlands north of the old wall, with Ningtiaoliang (寧條梁) in Jingbian County emerging as an important commercial center. In a telling sign of the new reign of peace, the town lacked a wall, though it was larger than any of the nearby political centers. As the MongolChinese border dissolved, growing numbers of Chinese migrants rented Mongol lands to bring the steppe under cultivation. While conflicts did not stop altogether, a generally peaceful coexistence prevailed on the northern frontier. ${ }^{34}$

Despite the return of peace and limited trade along the border, Shaanbei had suffered greatly from the famine and rebellions of the late Ming. With the population scattered or killed by natural and human disasters, most of the arable land had not been returned to production. For county after county, the provincial gazetteer reported taxable lands that were five to ten times the amount of land actually under cultivation. ${ }^{35}$ One early Qing official described the problem: "In the entire realm, Yan'an has the most wasteland, with hundreds of miles of bare mountains on all sides." To adjust for low yields in Shaanbei, the Ming system had counted between five and nine $m u$ (畧 = one-sixth of an acre) as one; but with inflexible tax quotas to fulfill from the reduced land under cultivation, Qing officials now demanded that one $m u$ of land pay taxes for six. This was rarely possible, and some counties were sixteen years behind on their tax payments. With good official connections, certain magistrates were able to gain reductions, but none were as low as 
the Ming rates. ${ }^{36}$ To attract new migrants to return arable land to cultivation, tax exemptions were offered for the first three years; but once that time elapsed, taxes were assessed at the full amount. That was nine times the Ming rate, and peasants simply packed up and moved on. ${ }^{37}$

One further fiscal problem had long plagued the province. Shaanxi was a critical point in the official post road system that linked the empire, and with more traffic going to the far west, the Qing expansion only made the problem worse. The roads, bridges, fords, post houses, and inns for official travelers had long been maintained by the general population through a system of corvée labor. The Qing had simplified and commercialized this system by collecting the corvée (ding 丁) tax as part of the land tax. In most of the empire, this amounted to a 20 percent increase in the land tax. ${ }^{38}$ In Shaanxi, the corvée tax was much higher, in some Shaanbei counties adding 80 percent to the land tax. ${ }^{39}$ One magistrate gained such popularity by closing post houses and eliminating tax-collecting fords that a shrine (shengci 生祠) was erected in his honor while he was still alive. ${ }^{40}$ Still, post houses and inns were essential to carry official messages and personnel in this vast, strategic, and sparsely populated borderland, so the taxes to support them remained high. ${ }^{41}$

Despite the heavy taxes, the early Qing was a fairly peaceful time in Shaanbei. One of the few exceptions was a 1667 uprising that seems more comical than threatening to the social order. The uprising, in the department of Suide, was led by a military officer from nearby Dingbian with the auspicious name Zhu Long (朱龍), or imperial dragon of the Ming ruling house. In Suide, a poor fellow called Fourth Son Zhou (周四儿) was injured in a mining accident, leaving a snakeshaped scar on his back that he called his "dragon in the flesh." Through some coincidence Zhou came to know Dragon Zhu, and one night a thief entered Zhu's room while he was asleep. Zhu woke and the clever thief knelt in a plea for mercy, saying he had been overcome by the red glow of the officer's body and a red dragon emanating from his nose. Dragon Zhu told this story to his new friend Zhou, who may well have arranged the whole incident. The red dragon was interpreted as a portent of imperial destiny, and Zhou suggested a rebellion. Dragon Zhu replied that his four or five hundred men were insufficient for the task, and Zhou promised that his impoverished home west of Suide could provide tens of thousands of followers with just 3,00o taels of silver. Zhu gave him the money, which Zhou used to buy a vast quantity of walnuts that were loaded on a dozen donkeys to return to his home.

Back in Suide, Zhou made a great show trading walnuts at a loss, buying dear and selling cheap. The starving villagers asked the source of his sudden wealth. He replied that his new friend, Dragon Zhu, had given him 10,00o taels to go into business, and he would loan it to them in small sums if they promised to repay the interest each month. Many were desperate for cash, and he carefully wrote down their names and ages and told them to return on the next market day. Zhou then rushed back to Dingbian, showed his ledger with the names of people he had 
allegedly enlisted in his army, adding that a show of force would stiffen their resolve. On the appointed day, Dragon Zhu and his troops hid nearby as Zhou went to the market. When the peasants came to pay their interest, Zhou revealed his plan to rebel. They protested that they had only come to pay their interest, but Zhou fired a signal shot and Zhu's force surrounded the market, executing several who refused to go along with the plan. That was enough for the rest, whom Zhou led to loot a nearby village. The booty from that raid attracted thousands more, who soon took the town of Suide when the magistrate fled and the local commander surrendered. The magistrate hurried to Xi'an with the seal of office, and a large Manchu force was dispatched to quell the uprising. While the incident showed that in the early Qing there were many famished peasants ready to follow a Ming pretender in rebellion, the quick suppression suggested that the new Manchu order was not under serious threat. ${ }^{42}$

\section{A CULTURE OF POVERTY}

Shaanbei was renowned for its poverty. With scant and unreliable rainfall and little irrigation, it was the classic region where the farmers "relied on Heaven to eat" (kao Tian chifan 靠天吃饭). Other than millet, beans, and sorghum planted on the bare plateaus and hillsides, there were few crops. Soybeans were rare, and doufu was not part of the diet. Tobacco was grown around Lanzhou in Gansu, but rarely on the Shaanbei plateau. There was too little water for cotton, and Shaanbei was too far north for mulberry and silkworms. This prevented the growth of the handicraft textiles common elsewhere in China. Cloth was imported, and Shaanbei men were renowned for wearing unlined sheepskin jackets year round. ${ }^{43}$ The only supplementary income came from flocks of sheep and goats tended by small boys, especially in the west along the Gansu border. ${ }^{44}$ Sometimes poor families rented sheep from the wealthy, which their sons herded for a portion of the wool. ${ }^{45}$ These herds provided the only local products of significant commercial value: the wool, hides, lambskin, and a few felt rugs that were traded for such necessary imports as cloth. ${ }^{46}$ Even pigs were scarce, and pork was rarely eaten. While the rest of China experienced significant commercial expansion, with teeming local markets, increased handicraft production adding women and children to the labor force, and local and regional divisions of labor raising productivity and improving living conditions, Shaanbei was left behind.

In addition to environmental limits on a diverse agricultural economy, the lack of convenient transport was a major barrier to the development of commerce. There were no navigable rivers anywhere in Shaanbei. All transport moved overland. Even in 1936, the one motor road reached only to Yan'an. ${ }^{47}$ In earlier times, traffic moved on narrow dirt trails that followed the twisting river valleys or wound up and down the hills. Dusty in winter and impassably muddy in the summer rains, one frustrated traveler found them "execrable."48 Lacking cheap water transport or even wheeled carts over the narrow trails, commercial traffic moved on 
mules, donkeys, or camels, making it exceptionally expensive. With little profit to be made, locals were not drawn to commerce, and the few merchants and artisans serving the local economy were largely outsiders, usually from Shanxi. ${ }^{49}$ Expensive and perilous transport made it extremely difficult to import grain in times of famine. ${ }^{50}$

With little commerce and a sparse population, Shaanbei had few towns of any size. Yulin, the military center of the region with a significant garrison and a strong wall, was probably the largest town, with a population of around ten thousand. Even Yan'an and Suide, the two political and cultural centers where the triennial official examinations were held, had less than that number. Most county seats in the region had one to two thousand residents, and a few like Ansai and Wupu had fewer than fifty families. ${ }^{51}$ In towns, as in the countryside, living conditions were exceptionally simple. As most visitors noted, the people lived in caves, though one should not imagine these dwellings as anything like the natural caverns of prehistoric peoples. The thick loess soil easily held a vertical slope, so it was possible to carve from the hillside a cave home with an arched ceiling and to cut an opening above for the stove's chimney, which also wound under and warmed the earthen bed or kang (炕). Once the walls had dried and been whitewashed, these caves were quite comfortable, cool in summer and easily warmed in winter. Prosperous families faced the front in stone, sometimes quite elaborately designed. ${ }^{52}$ Though cave dwellings were economical and comfortable, they were also the product of a significant shortage of wood. North of a band of forest that separated Shaanbei from the Wei River valley, the northern hills were basically barren. Not only did this deprive the local population of building materials, but fuel for cooking and heating posed a significant challenge. Stalks of corn and sorghum and such sticks as could be gathered from bushes provided the only fuel. ${ }^{53}$

The impoverished and "backward" local economy took its toll on the local population. The lives of the peasants and herders who made up the vast majority of Shaanbei denizens were bitter, to the extent that the local term for peasants was simply "hardship person" (shoukuren 受苦人)..$^{54}$ In gazetteer descriptions of local customs, no term is more common than "simple" (chun). Sometimes it was given a positive spin, establishing a link to the virtue of being simple and honest (chunhou 淳厚), and the official handbook giving capsule descriptions of each county praised the local population for showing no signs of extravagance. ${ }^{55}$ Given the poverty of the region, there was indeed little extravagance; but the real meaning of the term was certainly that the people were unsophisticated (chunpu 淳朴). Education was an expensive luxury for most families. In the words of the provincial gazetteer, "The land is barren and the people are poor; few attend school or are literate. As to the reason, most complain they are poor and have no resources for schooling, so that many clever youngsters end up spending their whole lives tilling the fields or tending flocks." ${ }^{56}$ One mid-Qing official found that in the first eighty years of the dynasty, eight counties along the northern border had not produced a single successful candidate in the provincial examinations. He asked the emperor 
for a special provision that one of the roughly fifty slots in the triennial examinations be reserved for these counties, a minimal act of affirmative action that was approved. ${ }^{57}$ With little contact with the wider world, Shaanxi was, in the words of an early twentieth-century Western visitor, "conservative and tradition-clinging even for China." ${ }^{58}$ Conservatism certainly did not bother the compilers of local gazetteers, but even Qing observers were troubled by prevalent popular beliefs that they regarded as superstitious. Much like the Communists in the twentieth century, they decried the widespread belief in ghosts and spirits and the reliance on shamans and spirit possession rather than medical professionals to cure illness. ${ }^{59}$

Twentieth-century visitors, both Chinese and Westerners, often complained that Shaanbei people were dirty. A typical visitor reported that Shaanbei people "are very dirty. They never bathe. They never used to even wash their faces. They bathe three times in a lifetime: at birth, marriage and death." ${ }^{60}$ There is little doubt that these accounts are accurate, but they reflect not inattention to hygiene but a lack of water. Especially for those who lived in hillside villages, a trip to the nearest stream might take half an hour, and not every household had ready access to a well. Complaints about the customs of Shaanbei people were not new. Qing dynasty writers were also troubled by what they saw. One Qing gazetteer noted five virtues: wealth was not a key consideration in marriage; righteousness was honored in friendship; the people were respectful of the dead and generous in their charity; and women were not seen in the markets. But it also noted one key failing. Shaanbei people were lazy: farmers did not irrigate their fields, grow vegetables, or plant trees; women did not spin or weave; and men did not engage in commerce. ${ }^{61}$ Modern visitors detected a certain stubbornness in these habits, finding the locals both lazy and proud. ${ }^{62}$

The classic expression of outsider views was a widely known poem by a Qing scholar cautioning his son against coming to Yan'an. He listed seven reasons, which read, in part

Pitiful scholars earn a licentiate's robes and then quit, their talent just enough to enter school when they stop writing, hanging a plaque above their gate and thinking it sufficient honor. They eat their simple steamed buns and never go on to Xian. As for examination success, forget it!

Pathetic women with messy hair full of cinders, rough blackened hands and a foul and putrid mouth. Her pants show her legs and her feet [which should be bound and small] are as wide as a donkey's hoofs. Where are the rolling waves of the bedchamber? As for beautiful painted ladies, forget it!

[Men in] unlined sheepskin jackets, worn all through the year without ever taking them off; tall, pointed winter caps; thick and wide padded pants, silk lining unthinkable in favor of what is rough and durable. At night, they cover themselves with a felt rug, never using a quilt. As for clothes of gauze and silk, forget it!

Guests are eagerly welcomed, children offering a rough pot of tea. You are feasted with panbread and scallions, peppers and vinegar, then thick flatbread with pickled vegetables. Ox and lamb hoofs, still covered with hair, are gobbled up in a rush. If you're thinking of fine seafood and delicacies, forget it! 
As for shelter, the low damp caves are made of earth; sunlight never enters in summer, and they leak in the rain. In the alcoves and on the sides, the walls are covered with soot from oil lamps. With horseshit and ox piss on the floors, the filth and stench are everywhere. If you are thinking of carved beams and painted pillars, forget it! $!^{63}$

Such descriptions betray both the arrogant disdain of officials from the wealthier parts of China and the vast cultural gap between them and the native population. On the other hand, the accuracy of such accounts should not be dismissed entirely. As we shall see below, when the Communists arrived in Shaanbei they too despaired that the "human material" was inadequate to make a modern revolution. ${ }^{64}$

It is important to remember that Shaanbei was a frontier zone, with the culture and habits of a land where pastoral and agricultural populations met. For much of China's early history the area was not inhabited by Han Chinese, and much of the modern population bears the marks of this diverse racial mix, with tall noses, strong jawbones, and even blue eyes. ${ }^{65}$ It is not surprising, therefore, that the population had many of the rough habits of the frontier. While the people were praised for being "simple," they were also described as "tough and fearless" (qianghan 强悍). ${ }^{66}$ Some gazetteers noted that, while these martial habits made the people loyal, they also made them willful, even arrogant. ${ }^{67}$ In Shaanbei, the success rate in the military exams was far greater than in the civil exams. ${ }^{68}$ The weak educational system made it difficult if not impossible to compete with the scholars of Guanzhong, and there were neither teachers nor local models of refined Confucian norms. Living in the outdoors and clambering over the hills as youths, young men learned to ride and shoot rather than to sit in a classroom and memorize the classics.

Shaanbei was not just a frontier but also a land of persistent natural and human disasters. We have seen the drought and rebellions of the late Ming, and both would return with a vengeance in the late nineteenth century. Such disasters inevitably turned much of the population into refugees. When the troubles subsided, the barren land was gradually repopulated by migrants from elsewhere. This was not a land of long-settled villages and ancient lineages with graveyards reminding the residents of multiple generations of ancestors. Lineage halls and genealogies were virtually non-existent. If a couple lacked an heir, it was common elsewhere in China to adopt from a brother or a cousin or at least within the patriline. In Shaanbei, however, such close relatives might not exist, so adoption outside the lineage was common. ${ }^{69}$ Weak lineages were the product of a mobile population of recent migrants, but given the importance of kinship elsewhere in China, their absence had a significant impact on local customs and culture.

When a migrant moved into a village, he might offer his young daughter to a local family in exchange for land rights. ${ }^{70}$ There was nothing unusual about giving away a daughter, but this arrangement gave an outsider access to village land and also made him the father-in-law of the young heir of a family with enough means to give away land. The practice was unusual enough for official comment, but it 
was not condemned. By contrast, the custom of women taking a second husband to care for her children, or even to support a disabled or unsatisfying first husband (zhaofu yangfu 招夫养夫), was definitely frowned upon. Matthew Sommer has examined instances of this practice in legal cases, and it was often a hired laborer who gained sexual access to a wife in exchange for his farm work. That appears to have been the case in Shaanbei, and it would be another example of the way in which mobile young men gained unusual status in village life. ${ }^{71}$ The most remarkable evidence of weak lineage structures was an inheritance practice reported in Dingbian, in the far northwest. While the usual practice gave equal inheritance rights to all male heirs, in Dingbian first priority went to a daughter's sons, then to the sons of the wife's sisters; only if none of these were available did the land go to sons in the patriline. An early twentieth-century survey said that this practice led to only 10 percent of the land staying within the patriline. ${ }^{72}$

In the 1930s, there were numerous reports that Shaanbei was rife with venereal disease. One sympathetic visitor to the Communist base wrote that "among Shaanbei people, 80-90 percent have VD."73 One consequence of poor hygiene, unsterile birthing practices, and widespread VD was an unusually high rate of infant mortality. ${ }^{74}$ Hostile witnesses blamed the VD on loose sexual norms brought by the Communists and the large number of single youths who flocked to the area after $1936 .^{75}$ It is likely, however, that years of warfare and revolution brought young soldiers into the region with sexual demands that were not conducive to genital hygiene. There were also Qing dynasty complaints of shared wives and casual sex. ${ }^{76}$ Though conventional sources are notoriously reticent about sexual practices, it is likely that high mortality rates leaving a substantial number of unattached widows, together with frequent mobility by young men in search of work and the comforts of home, produced conditions conducive to sexual mores that were looser than the Confucian norm.

In a land prone to natural and human disasters, the population was regularly replenished by migrants from other, more densely settled regions. As the son of one local official noted, young men who left their homes to seek their fortune preferred rich lands to poor, and nearby lands to far. Shaanbei was the last choice of migrants. In addition, new migrants had to borrow money for seed and tools to get started on new land. Wealthy households were few, and interest rates high. If they could not make enough to repay the loans, they just left and moved on. The net result was that those who came and stayed were unscrupulous rascals who cheated the local population and just made trouble. ${ }^{77}$ Another gazetteer offered an account of one form that this trouble might take: beggar bands as large as a hundred that called themselves "holy ants" (mama shen 螞螞神). With whole families of men, women, and children, on horses and donkeys but carrying no food, they begged in isolated villages, often stealing from untended households, or luring the women out and distracting them as one member of the gang went in to look for valuables. One nimble specialist carried a collection of keys to open the family lockbox and steal jewelry or valuables. While claiming to be famine refugees, they were really 
"lazy vagrants who do not work." ${ }^{8}$ Such combinations of refugees and unscrupulous rascals were the product of a harsh environment that offered little reward for long hours of harsh toil in the fields.

With an impoverished, mobile, and frequently unruly population, Shaanbei was an unattractive posting for a late Qing official. The provincial gazetteer reported that in the mid-Qing, there were few openings because honest officials lacking ambition often served for long terms. Then came the rebellions of the nineteenth century, to which we will turn presently. "For thousands of $l i$ [ 1 li equaling about one-half kilometer] there was no sign of life. . . Y Yan'an Prefecture was worst. A great prefecture was like a desert outpost. Whenever a vacancy occurred, most thought only of a few fine days in the capital; why would they think of devoting themselves to slow recovery?" The author, however, regarded this as more than a recent phenomenon: "Although this was in part the product of the times, we cannot exclude the fact that in [Qing] times they could not appoint talented men to secure order, but only those who treated office as a pasture or a place to redeem past failings." ${ }^{\prime 9}$ Shaanbei, it seems, attracted officials who had failed elsewhere, or those who sought to graze the local landscape for personal profit and then move on. The Bao'an gazetteer was equally downbeat: there was no joy in the posting, capable officials were rare, only timeservers coming. It had been this way since Ming times, when, according to an official of the time, local magistrates were either elderly lower-degree holders or petty education officials who had been promoted. When a man was selected for a Shaanbei posting he would appeal to friends and fellow officials to intercede on his behalf: his parents were old and he could not take a distant appointment; or his health was poor and he could not endure the cold. After several months of this he might get a better appointment. "The court selects officials to suit a locality; why should it select a posting for an official?"80

The number of local officials with regular examination degrees was fewer than half and declined over the course of the dynasty. The statistics in the provincial gazetteer confirm the impression of a Ming official: irregular appointments were frequent, and they increased over time. In addition, terms were short and getting shorter. In roughly a third of the cases, appointments were less than one year. Given the time it took to travel from Beijing, the appointment was probably never taken up. ${ }^{81}$ There are numerous examples of acting officials, often petty education officials who would not normally qualify for a magistrate posting. The undeniable conclusion is that the Qing state apparatus in Shaanbei was very weak.

The weak state structure was particularly important given Shaanbei's sparse gentry presence. In his classic work on the Chinese gentry, Chung-li Chang (Zhang Zhongli) wrote that "the gentry acted as intermediaries between the government officials and the local people." ${ }^{22}$ Local officials were, by law, prohibited from holding office in their native province. They were, inevitably, outsiders, and dependent on local elites to carry out their vast fiscal, judicial, educational, and security duties. As degree-holding members of local society, gentry possessed social status equivalent to local officials and unique access to them. Gentry cooperation was 
Mid-Qing Juren Distribution per 100,000 Pop. Over 10 Years

$\square<0.75$

$\square 0.75-1.5$

$\square 1.5-3$

$\square>3$

- County Boundary

River
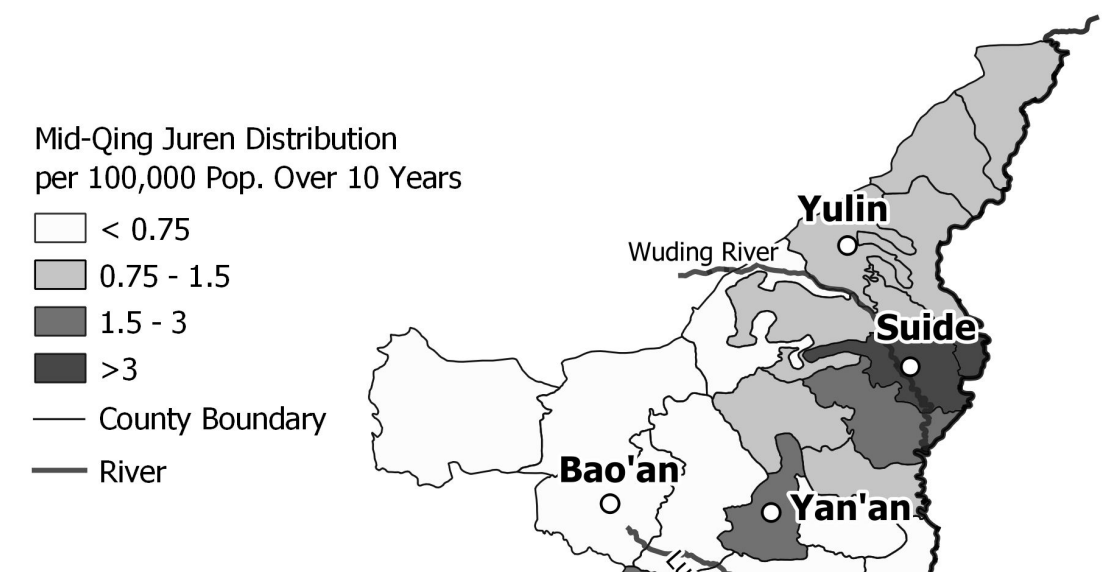

А
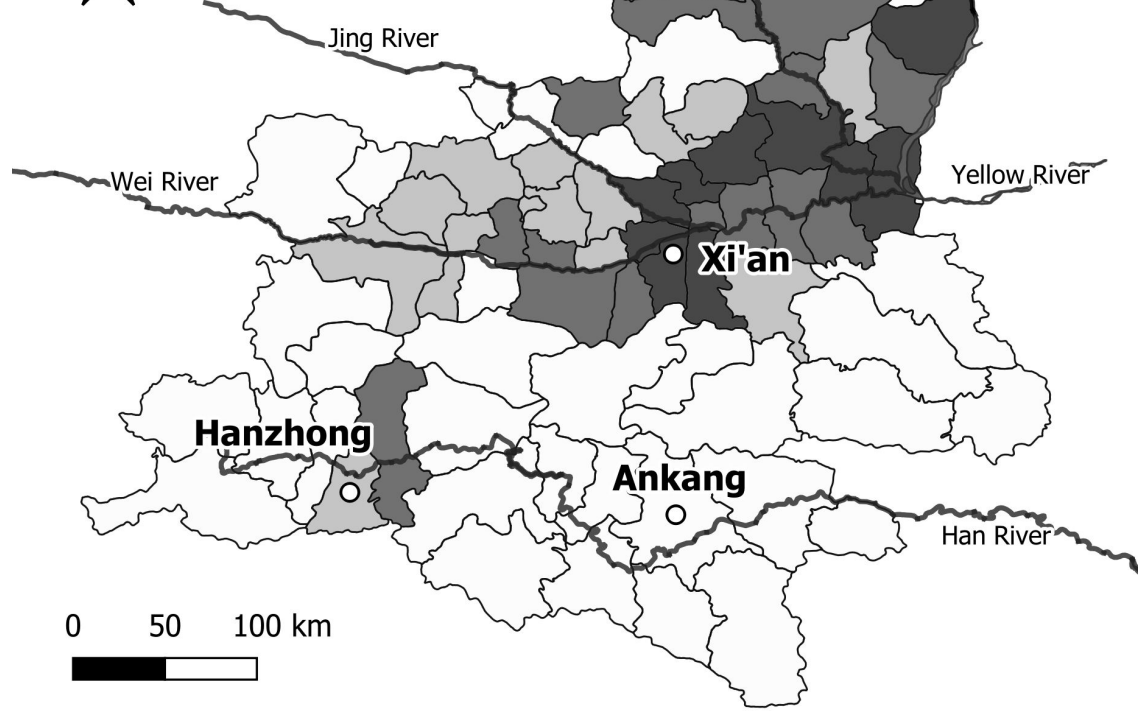

MAP 2. Mid-Qing (Qianlong-Jiaqing reigns) juren distribution by county: average number of provincial degrees awarded every ten years per 100,000 population. SOURCE: Juren figures from Shaanxi tongzhi xutongzhi 7:3505-3692; population from Shaanxi shengzhi: renkou zhi, $332 \mathrm{ff}$.

indispensable to the smooth operation of the polity. The problem, in Shaanbei, was that there were very few degree-holding gentry members to buttress the local regime. Formal gentry status required passing the provincial juren examination, but the weak educational system in Shaanbei meant that few local scholars could compete with the elites of Guanzhong. As map 2 shows, most of the Guanzhong heartland produced more than three juren per one hundred thousand population over ten years, while most of Shaanbei had fewer than half that number and a vast stretch along the Luo River had fewer than one-fourth. 
This meant that in most of Shaanbei, those with gentry status held the lower licentiate degree, a shengyuan, or what was colloquially called a xiucai. There was a local quota for licentiates, and while the quota was lower in the poor counties of Shaanbei, every county got some licentiates, even with minimal educational qualifications. As a result, in Shaanbei, gentry (shen) became the term used for local functionaries. In Jingbian, for example, the county was divided into five sections, each centered on a fortified stockade (bao or pu 堡) that was headed by a gentry chief (zongshen); then in the countryside, each section had four or five "dispersed gentry" (sanshen), each responsible for about twenty small villages. ${ }^{83}$ There was no suggestion that these gentry had any formal literary qualifications; they were simply rural functionaries called gentry to maintain social order in the countryside. This practice was so well established that in the republican era such rural functionaries as baojia officials of the Guomindang regime were routinely called gentry. ${ }^{84}$

\section{REBELLION}

As with much of China, the crisis came in the middle of the nineteenth century. As was often the case, Shaanbei was the passive victim of events that had their origin elsewhere. In most general histories, the crisis of the late Qing is associated with the impact of Western imperialism and the opening of China to trade, diplomatic missions, missionaries, and opium. In the Opium War of 1839-42 and the series of conflicts that followed through the nineteenth century, the proud Qing Empire was repeatedly defeated by the superior military forces of Britain, France, and finally Japan. These humiliating defeats spurred a process of reform and modernization that, while slow and halting, would eventually transform the Chinese nation. For most Chinese of the time, however, and certainly for residents of inland provinces like Shaanxi, it was not foreign invasion that affected them but domestic rebellions. Foremost among these was the Taiping Rebellion, which rose in the hills of southwestern China in 1850, established its capital in Nanjing in 1853, and occupied much of the Yangzi valley for over a decade. Inspired by a charismatic leader with an ersatz version of Christianity, vague notions of land reform and communal living, and a virulent hatred of the Manchus, the rebellion posed a direct threat to Qing rule and resulted in millions of deaths before Nanjing was retaken in 1864 and the last rebels were eliminated soon thereafter. ${ }^{85}$ Less organized and generally nonideological was the Nian Rebellion, a powerful force of rural rebels whose cavalry raided much of the North China plain from 1851 to $1868 .{ }^{86}$ Finally, in the southwestern province of Yunnan, a multiethnic rebellion with Muslim leadership established an independent sultanate that lasted from 1856 to $1873 .{ }^{87}$ These rebellions, plus the Muslim Rebellion that would rise in the Northwest, shook the very foundations of the Qing state and posed an existential threat to the established order.

As rebellion wracked much of the empire through the 1850s, Shaanxi remained peaceful. The relatively prosperous Wei River valley was able to provide soldiers, grain, and tax revenues to support the Qing defense against rebellion. Though 
the redeployment of resources produced cuts in some Shaanbei military rations and desertions by soldiers, the province seemed a bastion of peace and order in a time of turmoil. ${ }^{88}$ Still, Shaanxi remained sensitive to the threat of religiously inspired rebellion. The White Lotus Rebellion at the turn of the nineteenth century had disturbed southern Shaanxi for years, and the official account of the Muslim Rebellion was in an extended gazetteer section on "suppressing religious rebels" (pingding jiaofei 平定教匪) that began with the rise and fall of the White Lotus. ${ }^{89}$ Nineteenth-century Shaanxi officials were especially fearful of the powerful combination of religious commitment and political dissent.

In August 1861, the Xianfeng emperor died in his summer palace north of Beijing, having abandoned the capital to French and British occupation after his disastrous policies scuttled a peaceful resolution of the Second Opium War. The five-year-old Tongzhi emperor was installed on the throne, but foreign occupation and disarray in the court inspired the Taiping to launch another assault on Beijing. The campaign failed, but one Taiping column entered Shaanxi from the southeast and drove north toward the Wei River. ${ }^{90}$ With many Shaanxi soldiers fighting the rebels elsewhere, the authorities adopted the popular expedient of raising local militia to confront the Taiping incursion. Though local militia were effective in combatting rebels throughout the country, the Shaanxi justification included some unusual tactical details. Along with the conventional stress on gentry leadership and official support, the Shaanxi proposal noted the willingness of peasants to defend their homes and families but not to fight distant battles. It was essential to arm the peasants with firearms, but only a few days of training were necessary. Militia were most useful to deter rebels, their mere presence sufficient to alert rebel spies. If the rebels in fact attacked, the peasants, concerned mostly to protect their families, could not be expected to fight to the death; but they could fire their guns from a safe distance in an effort to scare off the enemy, then flee if the attempt failed. Finally, the particular advantage of local militia in mountain villages was noted. Knowing the mountain trails and local terrain, they could harass the enemy and pick off laggards in a long column. In addition, "Mountain people are simple, sturdy, brave and long-suffering. They are used to danger far more than the weak and fickle people of the plains." ${ }^{1}$

As Shaanxi began to organize and arm militia, local officials confronted a particular problem. The Wei River valley was home to a large number of Sino-Muslims called Hui or Huihui (回回). They had come to the area centuries earlier as traders but now spoke the local Chinese dialect and lived in separate communities organized around a local mosque and imam called an ahong (阿言). There were one to one and a half million Hui in Shaanxi, representing about one-tenth of the population, but almost half were concentrated in Tongzhou Prefecture, near the Shanxi border in the broad plain where the Wei, Luo and Yellow rivers came together. ${ }^{92}$ In the seventeenth century, Sino-Muslims further west had been influenced by Sufi sects originating in the Middle East, but the Shaanxi Hui adhered to a more conservative Gedimu tradition that sought common ground with Confucian 
ethics. Nonetheless, the different religious traditions, avoidance of pork and alcohol, separate communities, and rejection of intermarriage made ethnic tensions inevitable, so that racist stereotypes of Hui as haughty, violent, and foul-smelling were common. In his classic study of the Hui, Jonathan Lipman aptly described them as "normal but different, Sinophone but incomprehensible, local but outsiders." ${ }^{\text {"93 }}$ As a result of this ethnic divide, the predictable effect of militia organizing in Shaanxi was the creation of separate and competing Muslim and Han Chinese militia.

Community conflict was a constant feature of Chinese society. Lineages along China's southern coast engaged in bloody feuds that could last for generations, and conflict with one's neighbors could be an integral part of communal solidarity. ${ }^{94}$ Communal conflict between Han and Hui villages was a long-standing fact of life in Shaanxi, with Han complaining that Hui herds trampled their crops, and Hui objecting to discrimination in the local markets. As disputes persisted in the eighteenth century, the Manchu rulers abandoned their commitment to equal treatment of all ethnicities and endorsed harsher penalties toward Hui, whom they regarded as the aggressors. In 1862, a petty conflict over bamboo prices sparked the larger conflict. That the controversy began in a market was predictable, for this was the place where the two communities came together. Each side appealed to its agents among the yamen runners (tax and police agents in the local administration), but when the provincial militia commander, an intemperate member of the Han gentry, arrived to settle the dispute, he was killed, and rumors immediately spread that the Han intended to massacre the Hui in revenge. With Han and Hui both organized in militia, communal violence quickly escalated into outright rebellion until the entire Wei River valley was filled with bands of marauding Hui. Occasional incursions by Taiping and Nian rebels from the south added to the general chaos. The Qing state allied with Han militia in defense, and by the middle of the decade, with the exception of a small peaceful community in Xian, the Hui were driven from the province. ${ }^{95}$

The retreating Hui took refuge in Gansu, which already had a substantial Muslim population. Most assembled in Dongzhiyuan, a relatively prosperous valley in the poor east Gansu prefecture of Qingyang. From there, they made numerous attempts to return to their richer homeland in the eastern Wei valley. Traveling under the leadership of their imams in vast armed migrations including whole families of women and children, they were repeatedly blocked by Qing forces at the Shaanxi border. ${ }^{96}$ Despite appeals from their Gansu colleagues, the Shaanxi officials and gentry were adamant that the Hui should not return. In the words of the Shaanxi governor:

In my humble opinion, the Gansu Hui can be conciliated, but the time has not come where that is possible in Shaanxi. The Gansu Hui have always been simple and timid [yunuo愚懦]; they were coerced into joining the Shaanxi rebels. There is no deep enmity between them and the Han. The Shaanxi Hui, however, are both cunning and brazen [jiaohan 狡悍]; often pacified, they repeatedly rebel. Since the rebellion began, they have massacred hundreds of thousands of Han. If we were to err on the 
side of lenience, the people of Shaanxi, recalling the pain of their fathers and seeking the revenge due to sons, would certainly not live with them in peace. In addition, the property of the rebels has already been given to new migrants, who have sincerely followed our instructions. We certainly cannot take fields already tilled by others and turn them over [to former rebels]. If it is proposed that separate areas be laid out so that Han deal with Han and Hui deal with Hui, how could you expect the surviving Han to relinquish their lands to the surrendered Hui? The wrongs of the past are so deep that suspicions are sure to arise in the future. ${ }^{97}$

Simply put, the Guanzhong-based Han gentry and officials would not allow the Hui to return. Unfortunately, Shaanbei paid the price. The north was sacrificed for peace in the heartland. ${ }^{98}$

Hundreds of thousands of Shaanxi Hui had fled to Dongzhiyuan. In search of food, they began raiding the surrounding countryside, where in 1867 the harvest was already suffering from drought. ${ }^{99}$ Soon east Gansu villagers organized to protect their grain supply. Some were recognized as local militia, but when these defensive forces turned to extracting resources elsewhere, they became "militia bandits" (tuanfei). ${ }^{100}$ The result was precisely the mix of protective and predatory strategies that Elizabeth Perry has described among the Nian of the North China plain. ${ }^{101}$ Seeking first to defend their own communities, they were soon forced to prey on others. As stored grain was exhausted, unemployed farmers began raiding for food. As officials hoarded grain to feed the army, more peasants were forced into banditry. ${ }^{102}$ Soon they were leading bandit armies numbering in the thousands and adopting pithy noms de guerre: Smithy Gao the Second (高二鐵匠) or Fifth Master Zhang (張五大人). ${ }^{103}$ The most famous of these was Dong Fuxiang, a northern Gansu native who joined the militia to fight the Hui, then led an enormous army of his own until induced to surrender. He went on to play a major role in the suppression of the Hui Rebellion in Gansu and the far west, ending his career as a xenophobic general in the Qing army who led the siege of the foreign diplomatic quarter during the Boxer Uprising in 1900. ${ }^{104}$

As eastern Gansu was stripped clean, both Hui and bandits turned to Shaanbei. The worst years were 1866-67. Both groups moved down the Luo River, through Bao'an, and on to the counties beyond. Sometimes the Hui gathered bandits and ex-soldiers to add military strength to their bands; sometimes the Hui found the bandits unruly and sought to discipline them. Always, the sources stress, the purpose was foraging for grain. ${ }^{105}$ Some Hui clearly hoped to follow the Luo all the way to their homeland, where it flowed into the Wei River. As before, these were whole communities of women, children, and old people. At one point in 1867, the Hui sought an alliance with Nian rebels fighting in the area, in a vain attempt to acquire sufficient military strength to fight their way home. ${ }^{106}$

In the end, it was the peasants of Shaanbei who suffered. Shaanbei was weakly defended against this rebel onslaught, much of the military having been withdrawn to protect the provincial center or sent to fight the rebels in Gansu. ${ }^{107}$ Left to their own devices, the peasants fled to the walled towns, mountain-top 


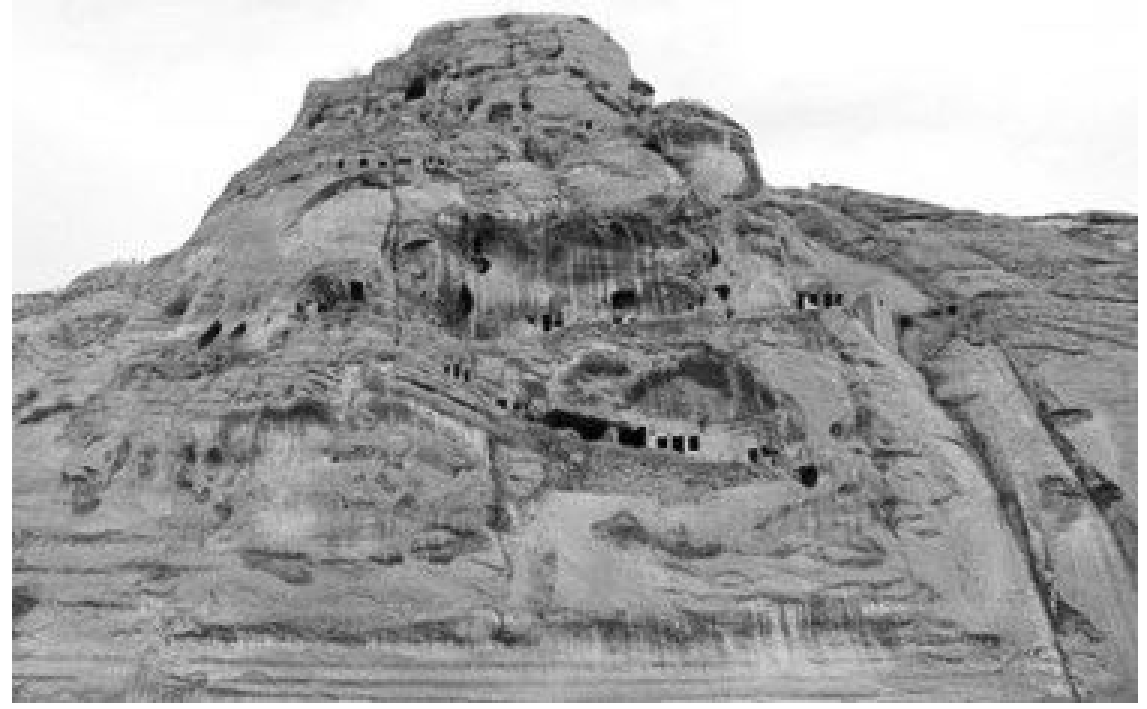

FIGURE 1. Yongningshan. This limestone fortress withstood the Muslim Rebellion and later served as a temporary refuge for the Bao'an County government.

stockades, or cliffside caves. The rebels and bandits were poorly armed: accounts have them fighting with swords or even rocks. Rarely did they have firearms. ${ }^{108}$ Sometimes, through sheer numbers, the Hui or local bandits breached the low and crumbling walls of a county seat, where they looted for food and treasure and killed or scattered the population. ${ }^{109}$ Mostly they raided isolated and undefended rural communities. ${ }^{110}$ The few and poorly paid government soldiers also looted the local population, so the peasants were made victims by both sides of the conflict. ${ }^{111}$

Bao'an, a poor county in the far northwest of the province and home of the Shaanbei Communist leader Liu Zhidan, provides a good example of the suffering brought by the rebellion. The Luo River ran through the county and provided an invasion route for both Hui and militia-bandits from Gansu. The small county seat was weakly defended with a crumbling wall. It quickly fell to the rebels, who looted everything valuable, destroyed the public buildings, and scattered the population. The magistrate fled, and no replacement came for three years. The county administration under a deputy magistrate relocated to the only secure location, the limestone mountain fortress of Yongningshan. With several levels of caves carved into the red limestone, access trails that were easily blocked, and a well that provided drinking water for a thousand, Yongningshan was the most secure of many such forts in Bao'an, and the refuge of the county government in republican times as well (see figure 1). Yongningshan was the one refuge that survived the rebellion. The other mountain forts all fell when the rebels besieged them and cut off their water. 


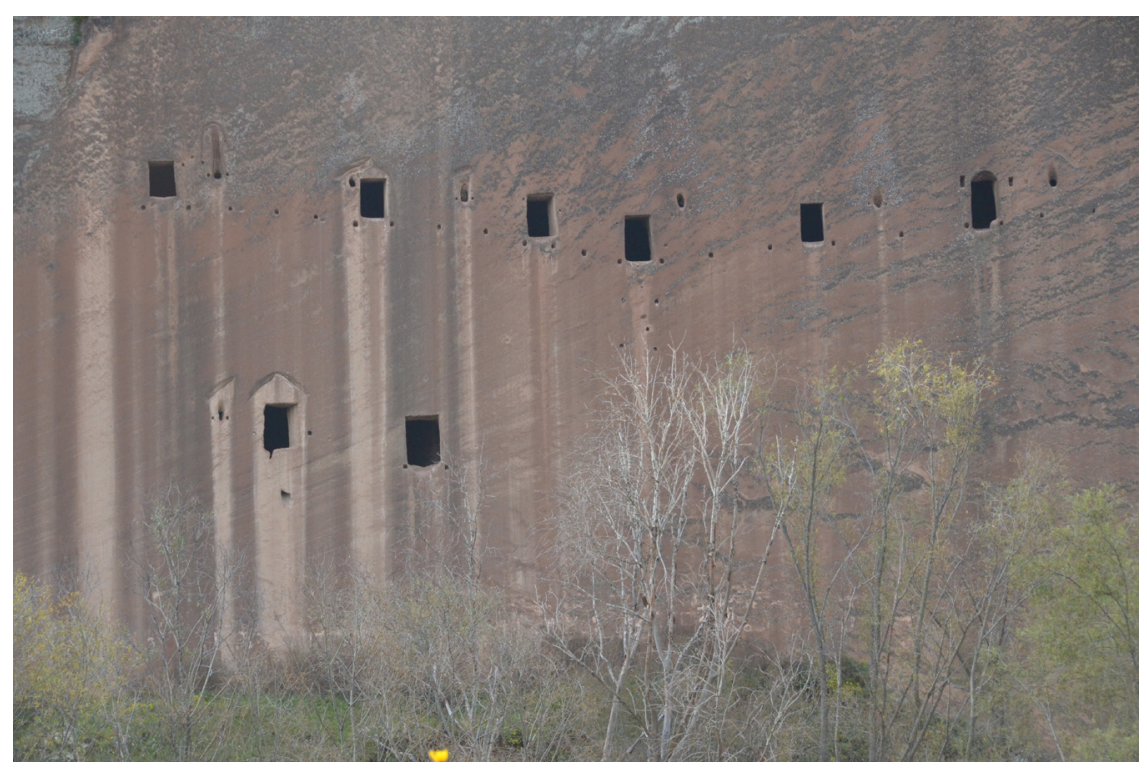

FIGURE 2. Cliff caves in Shaanbei. These caves served as a refuge from bandits or rebels. (Photo by author.)

In isolated villages, the usual defense against rebels or bandits was to retreat to a small cave cut in a steep rock hillside. The cave was accessed by a rope ladder that could be pulled up when the enemy approached, and food and water were moved inside for the emergency. Even now, one can see these cliffside refuges scattered throughout Shaanbei (see figure 2). These cliffside caves, however, were not always secure against hungry rebel hordes. Desperate for food, they would build a fire at the base of the cliff to asphyxiate the inhabitants, forcing some to leap to their death. Then, once the inhabitants had died or surrendered, a simple ladder was constructed to access the cave. In the end, most of the population fled or perished. Those who survived rallied to the support of local bandits for protection against the Hui, the devil whom you knew being preferable to the alien Other. When the rebellion was finally over, the government called for those who had cooperated with the bandits to turn themselves in. In a county whose pre-rebellion population was 51,500 , only 170 families responded to the call. ${ }^{112}$

\section{SUPPRESSION OF THE REBELLION}

Northwest China was governed by a single governor-general located in Lanzhou, the capital of Gansu. Through most of the Qing, this strategic position was held by a Manchu official. Gansu, however, was a poor province with over half the population Muslim. ${ }^{113}$ Many Hui joined the rebellion, and most were sympathetic. 
Understandably, Gansu officials favored more lenient pacification policies, but Shaanxi officials insisted on military suppression. In 1866, as rebellion raged across Gansu, a mutiny in Lanzhou forced the court to take decisive action. The Hunanese general Zuo Zongtang was appointed governor-general with a clear mandate to suppress the rebellion. By this time, however, the far west had fallen under an Islamic regime headed by Yáqub Beg from neighboring Khoqand. Zuo had been a crucial leader in the suppression of the Taiping Rebellion, and now his services were available for the last remaining threat to the dynasty. He was delayed for a year as he finished off the Nian rebels, but soon he began a systematic effort to return the vast Northwest to Chinese control. ${ }^{114}$

From the beginning, Zuo Zongtang's priority was the recapture of the far west. Xinjiang's Muslim-majority region had been added to the empire only during the Qing, and officials there had been Manchus and their Mongol allies. Zuo Zongtang's reconquest would bring it under Han Chinese rule, and he prepared carefully for the assault. Zuo was convinced that the Shaanxi-Gansu military was weak and unable to fight, and he was determined to bring his own army from central China. ${ }^{115}$ For this, he used his substantial connections in Shanghai to raise the funds for the men, arms, ammunition, and wagon trains to move his forces west. ${ }^{116}$ A zealous student of geography, Zuo was meticulous about logistics and planned for a protracted campaign. As his army paused for a time in Guanzhong, he busied his men repairing the roads and planting trees that shaded the route for a century. ${ }^{117}$ Methodical, resolute, and focused on the long term, Zuo carefully built his supply lines in a strategy that involved first pacifying Shaanxi, then defeating the Hui in Gansu, and finally reconquering Xinjiang. ${ }^{118}$ Unfortunately, Shaanbei, once again, would suffer in the process.

The problems resulted largely from Zuo Zongtang's supply lines. In addition to the main supply line through Guanzhong to Lanzhou and on to Xinjiang, there was a second supply line across Shaanbei to support the assault on the main Hui base in Jinjibao, on the east bank of the Yellow River as it flowed north into present-day Ningxia. Grain moved on pack animals along narrow trails from Shanxi, across the Yellow River, through a military garrison in Suide and then across the border counties of the north. Hui rarely ventured into this area-perhaps because their wish was to return to their homeland to the south. But the supply route became a prime target for bandit gangs and former soldiers, especially those under Dong Fuxiang, whose band numbered forty to fifty thousand at its peak. ${ }^{119}$

As Dong Fuxiang and others raided in the area, they picked up more local adherents as "the defeated bandits everywhere rallied to them." ${ }^{20}$ According to some accounts, Dong and these local bandits were better than the Hui and begged rather than raiding for food. ${ }^{121}$ Elsewhere, however, these "militia-bandits" were responsible for destroying the key border town of Ningtiaoliang, as well as the county seat of Jingbian. ${ }^{122}$ Eventually, in early 1869 , an arrangement was made. Dong Fuxiang's father approached Zuo Zongtang's key general with an offer 
to surrender. After some negotiations, an agreement was reached in which Dong's forces were enrolled as porters for Zuo's supply train. Dong soon proved himself as a fighter in the long battle against the Hui stronghold and began his rise in the Qing army. Shaanbei, at last, gained a measure of relief from rebel and bandit depredations. ${ }^{123}$

Two years earlier, however, another disturbance was a harbinger of trouble to come. In 1867, Zuo Zongtang's troops in Suide mutinied under the leadership of a Society of Brothers (Gelaohui) group from Hubei. The Society of Brothers, sometimes known as the Brothers and Elders, was a sworn brotherhood often called a "secret society," though later in Shaanbei its membership was hardly secret. It originated among soldiers and other unattached males in the Yangzi valley. With secret rituals for initiation and mutual recognition, it mostly served as a support network for young men, increasingly for those engaged in such semi-criminal activity as opium smuggling or protection rackets. It was prominent in the midYangzi military forces, and especially those of Zuo Zongtang, where it provided a degree of solidarity for men away from home in a dangerous occupation. As the incident in Suide and a similar mutiny further south demonstrated, the Society of Brothers could also provide leadership for acts of resistance. In Suide, the motives were purely economic. The soldiers were behind on their rations, and with their officers occupied elsewhere, the grain depot provided a ready target. They seized the granary, raided some local offices, and headed off in mutinous flight but were soon interrupted, apprehended, and roundly punished. The incident showed that along with a temporary peace, Zuo Zongtang's army had brought a disruptive new organization to the area. The Society of Brothers would play a leading role in the 1911 Revolution that ended Qing rule in Shaanxi, and it maintained substantial local power well into the era of Communist rule. ${ }^{124}$

\section{EFFECTS OF THE REBELLION}

The most obvious and measurable impact of the rebellion was a devastating reduction in the Shaanbei population. Gazetteers and official visitors routinely spoke of cities in ruin, traveling for great distances through the countryside without seeing a single family, and wolves roving through the mountains. ${ }^{125}$ Neighboring Gansu was the same, with Zuo Zongtang reporting that "all around the towns and forts have suffered massacre and plunder; there are hardly any people left. In [eastern Gansu], for a thousand $l i$ the fields are barren; one sees only white bones and yellow weeds. There are no signs of life, the horror of this disaster is unprecedented." ${ }^{126}$ Even fifty years later, a Western traveler noted "the daily sight of deserted and ruined villages" in Shaanxi and Gansu, which "have never recovered from the desolation of the Mohammedan Rebellion."127

Population figures from the late Qing are spotty and unreliable, so a precise accounting of the extent of devastation is impossible. In addition, the rebellion was 
followed by a ruinous drought in 1877-78, and the effects of the two disasters cannot be separated. The area along the Shaanxi-Gansu border was the worst affected. In Bao'an, an 1896 census counted only 8 percent of the pre-rebellion population, while early twentieth-century surveys in neighboring Ansai and Yan'an reveal 27 and 30 percent respectively. ${ }^{128}$ More immediate post-rebellion reports suggest that in Yan'an Prefecture only 20 percent of the population survived. ${ }^{129}$ In eastern Gansu, the situation was similar, with one plausible estimate of 70 percent population loss. ${ }^{130}$

The effects of the rebellion were long-lasting. I have calculated the population change between the relatively reliable census data of the 1820 s and the 1930s. The results are shown in map 3. The light band that runs from the northwest and generally follows the route of Hui and bandit raiders down the Luo River to the Wei represents the area of greatest destruction. As we shall see below, this was also the region in which the Communist guerrilla movement under Liu Zhidan would grow. Also important for the later history of Shaanxi is the significant population growth along the upper reaches of the Han River in southern Shaanxi. For our purposes, however, the most important trend is the rearrangement of the population centers in northern Shaanxi.

As the map shows, in contrast to the significant population drop in the west, the numbers in the northeast actually grew. Yulin, always the military center of Shaanbei, and neighboring Mizhi, whose magistrate had repaired the walls as the rebellion spread in the west and south, held off the rebels; and these counties saw their populations increase significantly after the rebellion. In Mizhi, the poor western region suffered from the rebellion, but wealthier villages east of the Wuding River had sturdy stockades where peasants could seek refuge during the relatively brief rebel incursions, and the local economy quickly recovered. ${ }^{131}$ Neighboring Suide, which hosted a substantial garrison along Zuo Zongtang's supply route, also grew, its 1902 population exceeding the pre-rebellion total. ${ }^{132}$ This growth was in part spurred by an increase in economic activity related to the distant treaty ports and global economy that were transforming coastal China. In the late nineteenth century, the popularity of fur coats and felt hats brought a growing demand for the traditional fur and hide exports of the Northwest. Representatives of foreign trading firms in Tianjin came to the Northwest to buy up the products of the local herds, and it was Shaanbei's more accessible northeastern counties that became the key entrepots. ${ }^{133}$ In Suide, some conservatives grumbled over the decline of traditional virtues as the new logic of the marketplace spread. ${ }^{134}$

As the economy of the northeast recovered, the local elite prospered as well. Map 4 gives a picture of late Qing gentry members (juren) as a percentage of population. As in the mid-Qing map 2, Shaanbei lagged far behind the prosperous counties of the Wei River valley, with their well-developed education systems and 


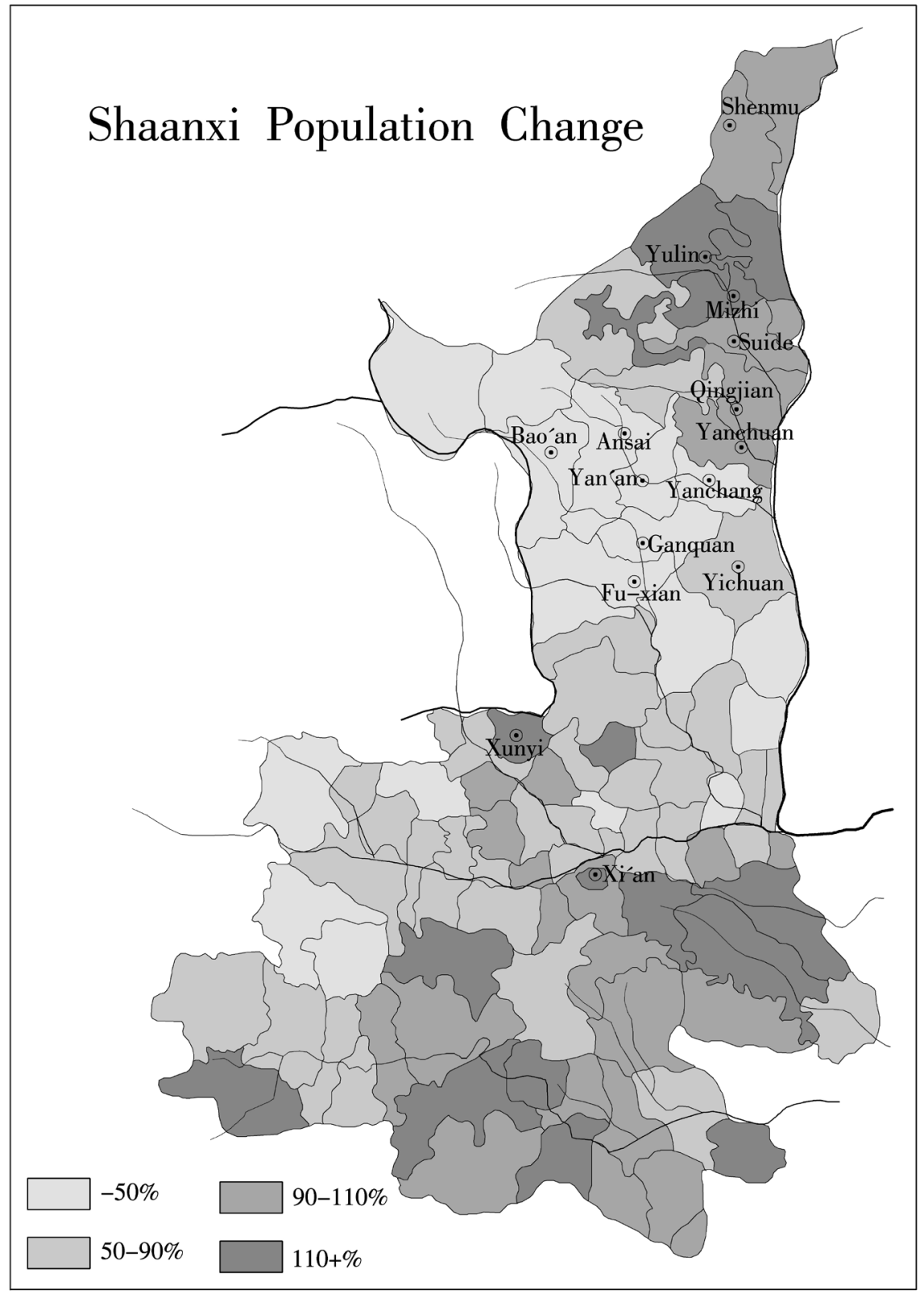

MAP 3. Shaanxi population in 1930 s as a percentage of 1820 s, showing demographic effect of Muslim Rebellion. There was a marked population decline west and south of Yan'an, while population increased in the northeast and in southern Shaanxi. SOURCE: Population for $1820 \mathrm{~s}$ same as Map 2. Population for 1930 is author's estimate based on July 1937 "Shaanxi gexian baojia hukou tongjibiao," Tongji cailiao yuekan 2, no. 5 (1937), and "Minguo 24 nian Shaanxi fenxian renkou shu," Tongji zailiao (1939). 


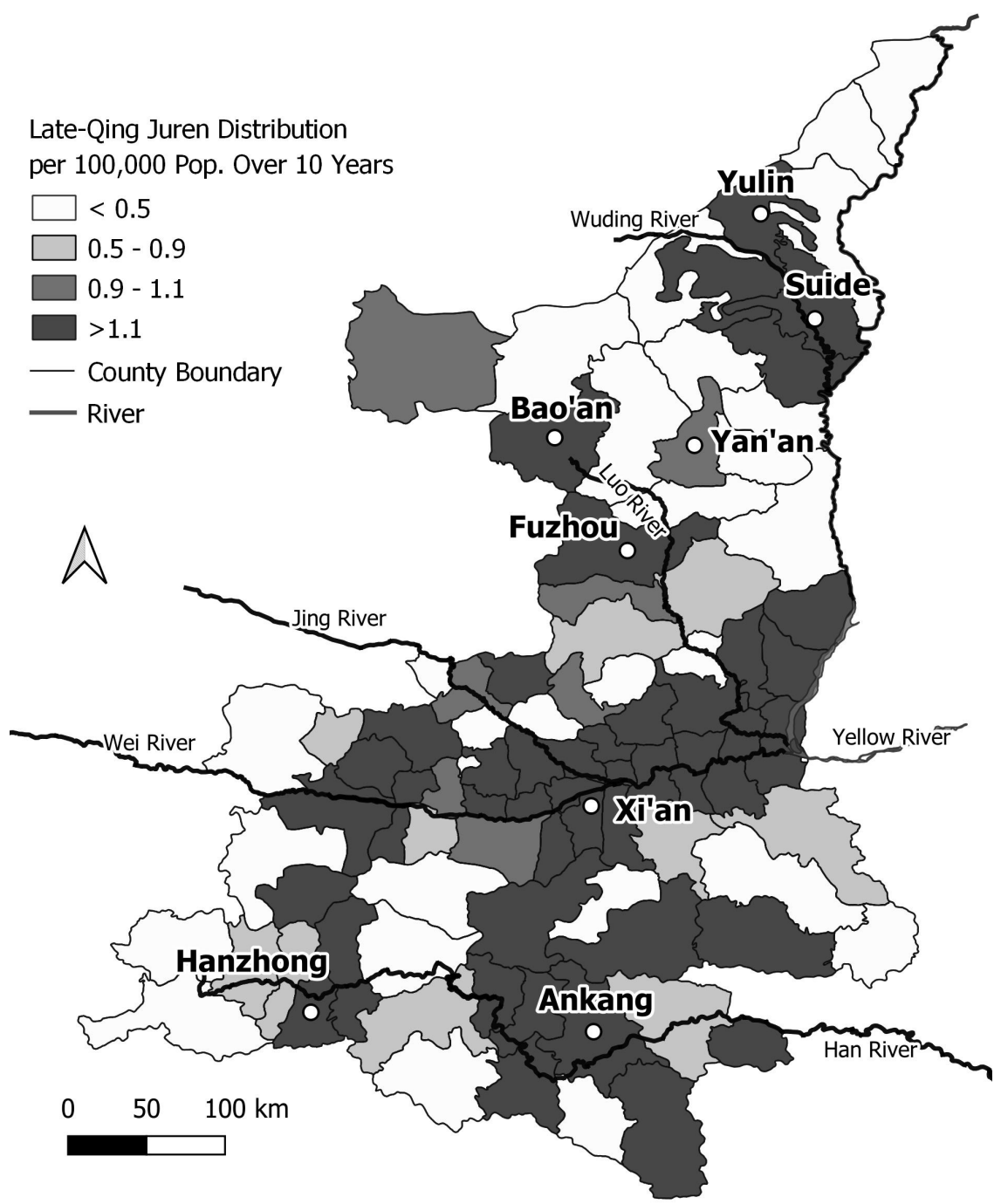

MAP 4. Late Qing (Tongzhi-Guangxu reigns) juren distribution by county: average number of provincial degrees awarded every ten years per 100,000 population. SOURCE: Juren figures same as Map 2; Population from 1930 same as Map 3.

established gentry networks. In addition, a comparison with map 2 reveals that southern Shaanxi was now competing successfully in the exams, while Shaanbei continued to trail behind. Within Shaanbei, the emergence of a dominant northeastern core that is shown by the population statistics is even more pronounced in gentry figures. Yulin and Mizhi were significant centers of gentry power with over three juren per hundred thousand population over forty years, comparable to most Guanzhong counties, though many in the Wei River valley (including 
counties where the population had been reduced by the elimination of the Hui) had twice this number. Suide, where the prefectural examinations were held, had a significant number, as did Fuzhou, which as an independent department was higher in the administrative hierarchy than an ordinary county. Yan'an, by contrast, went into sharp decline. As a prefectural capital, it produced a respectable nine juren in the mid-Qing reigns of Qianlong and Jiaqing (1735-1820). Then in the final years of the dynasty, it produced only two, compared to the eighteen from Mizhi and twenty-three from Yulin. The one apparent exception in the lagging northwest was Baoan. Its 1.8 juren per 100,000 population looks quite respectable until one realizes that this represents a single higher-degree holder (the only one in the entire Qing reign), an impressive achievement only because the county's post-rebellion population was so small. More importantly, further scrutiny reveals that the successful candidate was not from Bao'an at all but a native of Hubei, no doubt the son of an officer who had come with Zuo Zongtang's army. ${ }^{135}$

There were many ways in which a strong gentry influenced local governance. As we have seen above, degree-holding gentry were the social equals of county magistrates and served as effective representatives of the local community. One important function was leading appeals for tax remissions in times of poor harvests. As major landowners, the gentry were key beneficiaries of such relief, but the general population profited as well. Though Shaanxi suffered from major droughts in 1877-78 and again in 1900, most of the successful appeals for tax relief came from the Wei River valley, and in Shaanbei, from Yulin. ${ }^{136}$ In the late Qing, Mizhi and Suide became the cultural centers of Shanbei, with the best schools and the strongest landlord gentry elites. ${ }^{137}$ Mizhi lay between the political and military centers of Yulin and Suide and came to be recognized as a major cultural center, with a Confucian academy and a strong system of primary schools. ${ }^{138}$ These schools formed the foundation for the educational system of the republican era, with the northeastern counties along the Wuding River attracting students and future Communists from the entire region. As centers of education and orthodox gentry authority, this area stood in striking contrast to the counties of the northwest, where, as we have seen above, exam-qualified gentry were absent and the term gentry was applied to ordinary rural functionaries without academic qualifications.

\section{THE END OF EMPIRE}

At the dawn of the twentieth century, Shaanxi sank deeper into its modern status as a "backward" corner of the empire. The final decline of the Qing began in 1895, when its military was defeated by the forces of its rapidly modernizing neighbor, Japan. Ambitious reformers convinced the young Guangxu emperor to launch an impressive program of reform, but the Empress Dowager Cixi intervened to quash 
the effort and soon allied with xenophobic princes to support the antiforeign Boxer Uprising. This in turn sparked intervention by an international expedition, which occupied the capital and drove the court to refuge in Xian. There it rested in deep seclusion while foreign diplomats and Qing officials ultimately decided not to hold the empress dowager responsible for the Boxer catastrophe but to allow her to preside over the final years of the dying dynasty. ${ }^{139}$

Though later histories would focus on its impending demise, the last years of the Qing were in fact characterized by a vigorous program of economic, social, and political reform. The Confucian examinations were replaced by a modern school system whose curriculum included science and foreign languages. Students traveled abroad to absorb the new knowledge necessary for a modern state. A New Army was mandated with Western weapons and training. Industry was promoted, railways were built, and chambers of commerce were founded in cities across the country. In coastal cities, streets were paved, widened, lighted, and patrolled by police, while municipal reforms brought parks, museums, libraries, streetcars, and department stores. The imperial government replaced the old Six Boards with modern ministries of finance, communications, and foreign affairs and initiated constitutional reform with gentry-elected provincial and national assemblies. ${ }^{140}$

These dramatic changes had little impact in Shaanxi and none at all in Shaanbei. Shaanxi's New Army existed in name only, ${ }^{141}$ and provincial interests blocked efforts to build a railway to Xian with foreign loans. Mechanized industry was unknown; and education reform was slow and essentially confined to the Wei River valley. ${ }^{142}$ Elsewhere in China, great hope was placed in the constitutional reforms, designed to unify the country with a new sense of national purpose. Prominent gentry were elected to leading positions in the provincial assemblies, in preparation for constitutional government with a cabinet responsible to an elected legislature. ${ }^{143}$ Shaanxi, however, was a marginal participant in this movement, with Shaanbei particularly excluded. The provincial assembly franchise was essentially limited to gentry members, and the Shaanbei gentry was exceptionally weak. Only three of the sixty-six provincial assembly members came from Shaanbei, while twenty-two represented the provincial capital. ${ }^{144}$

On October 10, 1911, a mutiny among soldiers in Wuchang, the capital of Hubei Province, set off a revolution that soon spread through most of southern China and by February 1912 had toppled the Qing dynasty and ended two millennia of imperial rule. The 1911 Revolution launched China on nearly a century of revolution that would last until the Cultural Revolution finally convinced Chinese leaders that revolution was not always the best solution to the nation's problems. ${ }^{145}$ Shaanxi, on October 23, was one of the first provinces to join the revolutionary movement. The uprising in Shaanxi, however, differed markedly from that in the south, where progressive members of the provincial assemblies joined New Army officers to establish the new regime. In Shaanxi, by contrast, a small group of revolutionaries relied on the substantial influence of the Society of Brothers to carry out their insurrection. 
Anti-Manchu sentiment drove the revolutionary movement in Shaanxi. Students read old texts describing the Manchus' atrocities when they conquered China centuries earlier, and some Shaanxi scholars promoted arcane versions of Ming loyalism. In the quest for new learning, some students went to study in Japan, where they came in contact with Sun Yat-sen and other revolutionaries who in 1905 founded the Revolutionary Alliance (Tongmenghui 同盟會). Backward and isolated as Shaanxi was, Northwest students in Japan were few, and most came from a couple of schools in Xi'an and Sanyuan. About thirty joined the Revolutionary Alliance. ${ }^{146}$ On their return to China, many became teachers and quietly spread radical ideas in the new schools, but a few joined the army, where their anti-Manchu message was embraced by common soldiers in the Society of Brothers. As we have seen, the Society of Brothers came to Shaanxi with Zuo Zongtang's army from the Yangzi valley. For young men away from the comfort and companionship of home and family, the brotherhood offered a familiar and supportive community. Each lodge (tang 堂 or shantang 山堂) of the Brothers had its own leader, often a charismatic figure who might compete or cooperate with other leaders of the society. The rituals of sworn brotherhood, which included drinking the blood of a freshly killed chicken mixed with wine, created bonds of loyalty that are most comparable to those of the Mafia. ${ }^{147}$ The strength of the society, both in the army and later in bandit gangs in the north, made it virtually inevitable that revolutionaries - from the Revolutionary Alliance of the late Qing to the Communists of the 1930s-would join the Society of Brothers in search of young men willing to fight for their cause. ${ }^{148}$

In the summer of 1910, a number of young revolutionaries and Society of Brothers members gathered at Xi'an's famous Great Goose Pagoda (Dayanta 大雁塔) for a solemn blood oath of alliance against the Qing. ${ }^{149}$ Above all, the two groups were united in their opposition to the Manchus, whose large, idle, and ineffective garrison was a visible target of displeasure. When the Manchu governor cut salaries in the army, restlessness among the ordinary soldiers of the brotherhood increased. ${ }^{150}$

When the Wuchang Uprising broke out in the south, revolutionaries and Brothers in the Shaanxi army quickly met to respond. On October 22, they broke into the poorly guarded armory, distributed a mismatched batch of weapons and ammunition, and quickly took command of the city. The next day they launched an all-out assault on the Manchu quarter, breached the walls with their cannons, killed well over a thousand Manchus, and scattered the survivors to fend for themselves. With Society of Brothers soldiers in the lead, Xi'an witnessed the greatest massacre of Manchus in the country, but the city was now firmly in revolutionary hands. ${ }^{151}$

The revolutionaries now controlled Xian, but in North China, Shaanxi alone had joined the insurrection. The Manchu governor escaped to Gansu to organize an offensive from the west, and the court dispatched an army to take the fortress at Tongguan in the east. The new military government in Xian expanded the army from one brigade to eight regiments, which at full strength represented a fourfold 
increase. ${ }^{152}$ The key commanders proved effective in fighting off the Manchu loyalists, but the individual Society of Brothers lodge leaders each required a post for himself, resulting in four competing power centers. All of the focus was of course on the Guanzhong region. ${ }^{153}$ The north was left to fend for itself.

The schools that had nourished the Revolutionary Alliance scarcely existed in Shaanbei, so the 1911 Revolution there was entirely the work of the Society of Brothers. In Yulin, Brothers in the army led the uprising, targeting a corrupt prefect but also gaining a degree of cooperation from the local daotai until he was summoned to Xian and killed on the way. Most of the surrounding counties followed Yulin's lead to support the revolution, ${ }^{154}$ but in Suide, with its powerful militia and gentry leadership, the Society of Brothers "robbers" were executed or driven off. In Yan'an, the Society was reported to be "more numerous in proportion to the population ... than anywhere else in Shensi." The local military commander asked more funds to defend the city, but when the gentry refused, he fled. The local head of the Society of Brothers was an illiterate flour shop owner, and he was put in charge to maintain order. ${ }^{155} \mathrm{~A}$ similar process seems to have taken place throughout Shaanbei. Society of Brothers leaders in the army made deals with local elites and officials to assume or share power, and a new "revolutionary" regime was established. ${ }^{156}$

The new Republic of China soon proved a great disappointment. The Revolutionary Alliance represented a general discontent with Manchu rule, but real power lay with the powerful New Army in the north and its creator, Yuan Shikai. Yuan was a military man who had risen to a commanding position in the Qing bureaucracy before he was dismissed in 1909 by the regent for the young last emperor. In the end, the court was forced to recall Yuan as prime minister, from which position he negotiated the abdication of the emperor and his own elevation to president of the Republic. Yuan's generals soon became the warlords who dominated most of China. In Shaanxi, however, it was not Yuan's troops that held power but the commanders who rose with the Society of Brothers-led revolution. They and opportunist followers became the base of the new regime. Lacking funds, the Shaanxi warlords soon turned to promoting and taxing opium production to support their expanded armies. When soldiers went unpaid, they turned to banditry. Isolated from any prospect of economic development, the province lagged farther and farther behind the coastal regions. Shaanxi was certainly ready for another revolution. But it would be a long time coming. 